Ilmu Dakwah: Academic Journal for Homiletic Studies Volume 11 Nomor 1 (2017) 1-20 DOI: 10.15575 /idajhs.v11i1.1438

http://journal.uinsgd.ac.id/index.php/idajhs ISSN 1693-0843 (Print) ISSN 2548-8708 (Online)

\title{
Makna dan Aktualisasi Dakwah Islam Rahmatan lil Alamin di Indonesia
}

\author{
Harjani Hefni* \\ Institut Agama Islam Negeri Pontianak \\ "harjanihefnifuad@ gmail.com
}

\begin{abstract}
Rahmatan Lil alamin merupakan istilah al-Quran merujuk kepada tujuan utama dakwah yang diusung oleh Nabi Muhammad SAW. Istilah ini sering digunakan untuk menjelaskan bahwa Islam adalah agama yang damai, kasih sayang, toleran, dan cinta kebaikan. Namun dalam al-Quran, hadis dan sejarah dakwah Nabi Muhammad dan para sahabatnya menunjukkan bahwa tidak semua aktivitas bertujuan untuk menegakkan rahmatan lilalamin bisa dihadirkan dengan damai, kasih sayang, toleran, dan cinta kebaikan, tetapi ada juga konsep jihad, amar ma ruf nahi munkar dan wala dengan sesama mukmin. Tulisan ini mencoba untuk menggali makna rahmat dalam alQuran serta bagaimana cara mewujudkannya dengan pendekatan metode tafsir tematik. Berdasarkan hasil penelitian ditemukan makna rahmatan lilalamin akan terwujud manakala terjadi keseimbangan hablun minallah dan hablun minannas, yaitu menerapkan dua belas aktivitas yang terkait dengan hubungan hablun minallah dan dua belas aktivitas yang terkait dengan hablun minannas.

Keywords : Dakwah Islam, Hakikat Makna; Aktualisasi; Rahmatan Lil alamin
\end{abstract}

\section{ABSTRAK}

Rahmatan Lil alamin merupakan istilah al-Quran merujuk kepada tujuan utama dakwah yang diusung oleh Nabi Muhammad SAW. Istilah ini sering digunakan untuk menjelaskan bahwa Islam adalah agama yang damai, kasih sayang, toleran, dan cinta kebaikan. Namun dalam al-Quran, hadis dan sejarah dakwah Nabi Muhammad dan para sahabatnya menunjukkan bahwa tidak semua aktivitas bertujuan untuk menegakkan rahmatan lil alamin bisa dihadirkan dengan damai, kasih sayang, toleran, dan cinta kebaikan, tetapi ada juga konsep jihad, amar ma ruf nahi munkar dan wala dengan sesama mukmin. Tulisan ini mencoba untuk menggali makna rahmat dalam alQuran serta bagaimana cara mewujudkannya dengan pendekatan metode tafsir tematik. Berdasarkan hasil penelitian ditemukan makna rahmatan lilalamin akan terwujud manakala terjadi keseimbangan hablun minallah dan hablun minannas, yaitu menerapkan dua belas aktivitas yang terkait dengan hubungan hablun minallah dan dua belas aktivitas yang terkait dengan hablun minannas.

Kata Kunci : Dakwah Islam, Hakikat Makna; Aktualisasi; Rahmatan Lil alamin

Diterima: Mei 2017. Disetujui: Juni 2017. Dipublikasikan: Juni 2017 


\section{PENDAHULUAN}

Pemberitaan yang begitu massif terhadap Islam dan perilaku sebagian penganutnya yang dianggap melakukan perbuatan teror berhasil membuat sebagian kalangan apriori terhadap Islam dan takut untuk belajar Islam. Di tengah kondisi seperti ini istilah rahmatan lil alamin menjadi model alternatif Islam yang didamba-dambakan oleh banyak kalangan. Sayangnya, istilah ini dimaknai secara liar tanpa ada landasan ilmiah yang memadai, bahkan bisa dikatakan bias makna.

Jokowi ketika kampanye pemilihan presiden beberapa waktu lalu mengatakan bahwa dirinya berislam yang rahmatan lilalamin. Kalau disimak maksud dari rahmatan lil alamin versi Jokowi adalah tidak akan menyimpan kekayaan yang berasal dari hasil rampokan, tak akan korupsi, tidak hidup bermewah-mewah, tidak menciptakan perang bagi sesama pemeluk Islam, tidak menindas agama lain, dan tidak bersikap arogan (Sufa, 2014). Dalam kesempatan yang lain, Pemerintah Republik Indonesia yang sudah merasa berislam yang rahmatan lil alamin dengan percaya dirinya mengajak Pemerintah Saudi Arabia untuk berislam yang rahmatan lilalamin (Sufa, 2014). Ajakan itu seolah-olah menyiratkan bahwa Indonesia adalah model Islam rahmatan lilalamin yang layak untuk dicontoh.

Karena tidak adanya batasan tentang makna ini, banyak kalangan menggunakan istilah ini sebagaimana yang mereka pahami. Memahami istilah rahmatan lilalamin dalam kondisi aman, tidak ada masalah antar umat yang berbeda agama. Tetapi jika terjadi konflik, bagaimana menerapkan rahmatan lil alamin? Pertanyaan selanjutnya yang akan muncul adalah, apakah ketika terjadi perang, karena kondisi tertentu yang sering terjadi pada jaman Nabi, Nabi dan para sahabatnya dianggap tidak menjalankan visinya yang rahmatan lil alamin?

Penelitian ini dianggap sangat penting karena kata rahmat sering dipahami parsial bahkan kabur oleh sebagian orang. Gambaran umum tentang rahmat di kepala sebagian orang adalah kelembutan dalam dakwah tanpa menyentuh ruang nahyu munkar terhadap orang yang tidak akomodatif terhadap kebenaran. Pemahaman yang parsial seperti ini melahirkan sikap dan tindakan yang juga parsial. Sebagian orang menjadi tidak setuju jika sebuah tindakan secara lahir bertentangan dengan kelembutan, karena menurut mereka tidak sejalan dengan makna rahmat .

Studi ini menjadi terasa semakin penting ketika isu tentang ISIS (Islamic State of Irak and Syria) serta gerakan teroris lainnya menghiasi 
berbagai media. Seolah-olah menampilkan dirinya sebagai representasi Islam yang sebenarnya.

Sebelum penelitian ini, ada beberapa tulisan yang terkait dengan rahmatan lilalamin, di antaranya tulisan Abu Syuja al-Ishlahy yang menulis tentang makna rahmatan lilalamin yang tertuang dalam al Quran Surah al-Anbiya ayat 107. Fahmi Zarkasyi (2011) dalam tulisannya rahmatan lilalamin mencoba untuk meluruskan istilah mengusir, menaklukkan, dikuasai, ditundukkan, yang sering digunakan oleh para penulis sejarah terkait dengan interaksi muslim dan non muslim, terutama pada saat kejayaan kaum muslimin. Seluruh istilah itu berdasarkan fakta sejarah menurut penulis lebih tepat diganti dengan kata menyelamatkan dan membebaskan. Selain mengkaji dari aspek historis, penulis juga mengangkat aspek lain dari rahmat Islam. Kesimpulannya, rahmat Islam ada konsep keseimbangan hidup. Abuddin Nata (2016) juga menjelaskan makna rahmatan lilalamin yang cukup memadai. Penulis meneliti rahmatan lilalamin dari pendapat ahli tafsir dan dari aspek praktik keislaman yang dilakukan oleh Rasulullah saw.

Peneliti berusaha untuk melakukan studi mendalam tentang hakikat rahmat secara konseptual sebagaimana yang tertuang dalam alQuran. Selanjutnya, studi seharusnya diarahkan kepada bagaimana konsep ini dapat dibumikan pada zaman Rasulullah saw. Kisah sukses menerapkan konsep rahmatan lilalamin pada jaman Nabi merupakan informasi penting yang bisa diambil pelajaran oleh Bangsa Indonesia untuk mewujudkannya di bumi Indonesia. Tetapi, mengingat luasnya kajian ini, peneliti membatasi diri untuk meneliti makna rahmat dalm alQuran dengan menelusuri seluruh ayat yang terkait dengan rahmat.

\section{HASIL DAN PEMBAHASAN}

Dakwah rahmatan lil alamin adalah dakwah Rasulullah yang mengajak manusia ke jalan Allah dengan semangat dasar kelembutan dan kasih sayang, dengan cara berpegang teguh dengan al Quran dan mengikuti jalan hidup Nabi, agar mendapatkan barokah di dunia dengan rezeki yang cukup, hujan yang cukup, dan tanah yang subur serta mendapatkan nikmat surga di akhirat kelak. Rumusan di atas diramu dari tujuh makna rahmat dalam al-Quran: pertama, kelembutan (riqqah), empati (ta aththuf), memberikan maaf (maghfirah), penyayang (hanan) yang merupakan lawan kata dari azab, kejahatan, kemudharatan, kekasaran. Kedua, rezeki. Ketiga, kenabian. Keempat, tanah yang subur. Kelima, alQuran. Keenam, hujan. Ketujuh, surga. 
Dakwah Rahmatan lil alamin mengajak manusia untuk menjadi manusia yang utuh dengan memperhatikan aspek fisik, psikis, akal, maupun fitrah, dan memperhatikan dengan seksama kehidupan orangorang yang beriman.

Untuk mewujudkan Islam rahmatan lilalamin, al-Quran dan hadis mengajarkan nilai keseimbangan antara hablun minallah dan hablun minann $s$.

Hablun minallah tergambar dalam duabelas poin, yaitu: 1). Beriman kepada Allah dan berpegang teguh dengan keimanan; 2). Menaati Allah dan Rasul-Nya; 3). Mendirikan sholat; 4). Memakmurkan masjid; 5). Mengkaji ayat-ayat Allah di masjid; 6). Merasa diri banyak memiliki kekurangan dan berdoa supaya mendapatkan rahmat; 7). Istighfar, taubat, dan memperbaiki diri; 8). Mengikuti al-Quran dan mendengarkannya dengan seksama; 9). Bertaqwa; 10). Berjihad dengan harta dan jiwa; 11). Sabar ketika menghadapi musibah; 12). Tawakkal kepada Allah. Sedangkan ajaran tentang Hablun Minann $s$ tergambar dalam duabelas berikut: 1). Profesional dalam bekerja; 2). Saling berwala dengan sesama mukmin; 3). Amr ma ruf nahi munkar; 4). Membayar zakat; 5). Berbuat baik kepada orang tua; 6). Ukhuwwah yang dibangun di atas dasar taqwa; 7). Hijrah; 8). Menjadi orang saleh; 9). Infaq fi sabilillah untuk mendekatkan diri kepada Allah; 10). Makan harta yang baik; 11). Berbuat baik kepada orang lemah, orang sakit, dan orang miskin; 12). Berlomba melakukan kebaikan di antara suami dan istri.

Baik aspek hablun minalah maupun aspek hablun minannas sudah dipraktekkan oleh Rasulullah dalam kehidupan pribadi, bermasyarakat, bernegara. Dengan dipraktekkannya kedua unsur itu secara seimbang maka seluruh makhluk, manusia, hewan, maupun tumbuhan merasakan kasih sayang dan sentuhan kenyamanan dan rahmatan lil alamin dari ajaran Islam.

Perbedaan studi ini dengan penelitian dan tulisan yang sebelumnya terletak pada pendekatan. Perbedaan pendekatan melahirkan hasil yang juga berbeda. Peneliti dalam tulisan ini mendudukkan makna rahmatan lil alamin di dalam al-Quran dengan menelusuri kata rahmat yang disebutkan dalam al-Quran. Penelitian yang menggunakan tafsir maudhu i ini diharapkan mampu memberikan makna konseptual yang utuh tentang rahmatan lil alamin. Hasil penelitian ini diharapkan bisa melengkapi penelitian sebelumnya dan dapat dijadikan acuan untuk mengomunikasikan prinsip Islam kepada masyarakat, terutama pada masyarakat antar umat berugama dan menjadi model untuk intern umat Islam dalam mempraktekkan ajaran Islam dalam ruang kehidupan 
pribadi, keluarga, masyarakat, negara, bahkan antar negara, baik dengan sesama umat Islam maupun dengan masyarakat non Islam. Buat pihakpihak yang keliru memandang Islam karena melihat oknum beberapa gelintir umat Islam yang tidak merepresentasikan nilai-nilai Islam yang sebenarnya, mudah-mudahan setelah membaca hasil studi ini dapat memformulasikan kembali sikapnya yang keliru terhadap ajaran-ajaran Islam.

\section{Makna Kata Rahmat Dalam Al-Quran}

Cara yang paling tepat untuk memahami makna kata rahmat yang terdapat dalam al-Quran adalah dengan mempelajari kata rahmat yang digunakan dalam al-Qur an. Kata rahmah dalam al-Quran digunakan untuk tujuh makna, yaitu : Pertama, Rahmat berarti kelembutan (riqqah), empati (ta aththuf), memberikan maaf (maghfirah), penyayang (hanan). Dalam konteks ini, rahmat adalah lawan kata dari azab, kejahatan, kemudharatan, kekasaran. Makna ini ditunjukkan dalam QS.Al-Anbiya : 107, QS. Al Balad: 17, QS.A1-Kahf : 81, Shahih Bukhari, No.2900.

Kedua, Rahmat berarti rezeki. Rezeki disebut rahmat karena ia merupakan salah satu bentuk kasih sayang Allah yang paling menonjol pada makhluk-Nya. Tidak ada satu makhlukpun yang tidak mendapatkan jatah rezeki dari-Nya. Ini terdapat dalam QS. AI Isra : 28, Maksud ayat ini apabila kamu tidak dapat melaksanakan perintah Allah untuk berinfak, maka katakanlah kepada mereka perkataan yang baik agar mereka tidak kecewa lantaran mereka belum mendapat bantuan dari kamu. Setelah itu kamu berusaha untuk mendapat rezki (rahmat) dari Tuhanmu, sehingga kamu dapat memberikan kepada mereka hak-hak mereka.

Ketiga, Rahmat berarti kenabian.Kenabian atau diutusnya Nabi menjadi identik dengan rahmat karena ia membawa nilai-nilai yang membawa rahmat untuk umatnya. Ayat yang mendukung makna ini adalah firman Allah di dalam QS.Al Baqarah 105 dan Hud 28, QS. AI Baqarah : 105.

Keempat, Rahmat berarti tanah yang subur. Tanah subur adalah salah satu indikator rahmat yang langsung dirasakan oleh manusia, karena itu ia dianggap sama dengan rahmat itu sendiri. Untuk makna ini Allah swt berfirman dalam QS.Yunus :21 Dan apabila kami merasakan kepada manusia suatu rahmat, sesudah (datangnya) bahaya menimpa mereka, tiba-tiba mereka mempunyai tipu daya dalam (menentang) tanda-tanda kekuasaan kami. 
Kelima, Rahmat berarti al-Qur an, Al Quran disebut rahmat karena al Quran adalah rahmat paling besar yang diturunkan Allah kepada manusia. Karena al Quran, manusia mendapatkan panduan hidup yang menyelamatkan hidupnya di dunia dan akhirat. makna ini Allah swt berfirman sesuai dengan QS.Y unus : 57

Keenam, Rahmat berarti hujan. Di antara makna rahmat dalam alQuran adalah hujan. Hujan dinamakan rahmat karena dari airlah sumber kehidupan, dan karena air kehidupan ini menjadi nyaman. Tanpa air maka semua akan menjadi punah. Untuk makna ini Allah berfirman dalam QS. Al A raaf : 57

Ketujuh, Rahmat berarti surga. Surga merupakan anugerah tertinggi Allah untuk manusia di akhirat. Masuknya orang ke surga adalah murni karena rahmat Allah. Ayat yang mendukung makna ini adalah firman Allah Ayat yang mendukung makna ini adalah firman Allah.

Enam makna rahmat terakhir bukanlah makna rahmat yang sesungguhnya, tetapi identik dengan rahmat karena enam hal di atas langsung dirasakan oleh masyarakat sebagai bentuk kebaikan dan kemaslahatan dari Allah untuk hidup mereka di dunia maupun nanti di akhirat..

Berdasarkan makna rahmat di atas, dapat dirumuskan bahwa tugas dakwah Rasulullah sebagai berikut: mengajak manusia ke jalan Allah dengan semangat kelembutan dan kasih sayang, dengan cara berpegang teguh dengan al Quran dan mengikuti jalan hidup Nabi, agar mendapatkan barakah di dunia dengan rezeki yang cukup, hujan yang cukup, dan tanah yang subur serta mendapatkan nikmat surga di akhirat kelak .

\section{Konsep Rahmat Dalam al-Quran}

Seluruh bentuk kebaikan dan segala hal yang bermanfaat untuk manusia di dunia ini maupun nanti di akhirat masuk dalam kategori rahmat. Rahmat adalah lawan kata mudharat dengan segala macam bentuknya. Rahmat adalah salah satu sifat Allah yang paling utama. Dia selalu mengedepankan sifat ini dari sifat lainnya dalam memilih, menetapkan, dan memprioritaskan semua perkara. Ayat dan hadis berikut ini mendukung pernyataan di atas. Allah swt berfirman : Katakanlah: "Kepunyaan siapakah apa yang ada di langit dan di bumi." Katakanlah: "Kepunyaan Allah." dia Telah menetapkan atas Diri-Nya kasih sayang. ( QS. Al An am : 12). Allah swt menegaskan dalam hadis qudsi: إن رحمني Sesungguhnya rahmat-Ku selalu mengalahkan kemurkaan- 
$K u$. Ayat yang mendukung makna ini adalah firman Allah di dalam QS.Al Baqarah 105 dan QS. Hud 28.

Sifat rahmat Allah juga diturunkan kepada Nabi Muhammad. Dengan dasar sifat ini, Rasulullah menebarkan Islam.

Maka disebabkan rahmat dari Allah-lah kamu berlaku lemah lembut terhadap mereka. Sekiranya kamu bersikap keras lagi berhati kasar, tentulah mereka menjauhkan diri dari sekelilingmu. Karena itu maafkanlah mereka, mohonkanlah ampun bagi mereka, dan bermusyawaratlah dengan mereka dalam urusan itu ${ }^{1}$. Kemudian apabila kamu telah membulatkan tekad, maka bertawakkallah kepada Allah. Sesungguhnya Allah menyukai orang-orang yang bertawakkal kepada-Nya. (QS. Ali Imran : 159)

Sifat rahmat ini diwariskan oleh Rasulullah kepada para sahabatnya. Rasulullah saw bersabda:

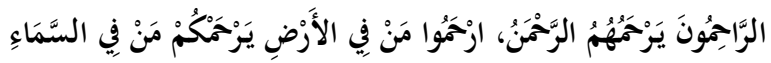

Orang-orang yang berkasih sayang disayangi oleh Yang Maha Penyayang. Kasihilah orang yang ada di bumi, niscaya Yang di langit akan menyayangi kalian. (Al-Tirmidzi, 1975: 388).

Kesinambungan sifat rahmah dari Allah kepada Nabi dan kepada para sahabatnya menjadikan konsep rahmat menjadi kukuh dalam ajaran Islam.

Meskipun sifat rahmah dengan tampilan utamanya adalah keakraban, kelembutan, dan kasih sayang, tetapi sifat-sifat tersebut tidak menghilangkan keperkasaan, keberanian, dan ketegasan mereka dalam menghadapi kedurjanaan, kedzaliman, penyimpangan, dan segala macam bentuk manipulasi. Orang kafir adalah salah satu komunitas yang dihadapi oleh Rasulullah dan sahabatnya dengan tegas, karena mereka tidak obyektif dalam menyikapi kebenaran. Sesuai dengan katanya, kafir berarti upaya untuk membenamkan fakta ke dalam lumpur yang dalam. Itulah sebabnya petani di dalam bahasa Arab disebut kafir, artinya orang yang berprofesi membenamkan biji ke dalam tanah. Di antara data yang mereka sembunyikan adalah data tentang kenabian Muhammad. Ketegasan Rasulullah dan para sahabat kepada orang kafir murni disebabkan oleh ketidakobyektifan mereka menyikapi kenyataan yang tidak berpihak kepada mereka, lalu berusaha dengan segala cara untuk 
melenyapkan eksistensi kebenaran yang diusung oleh kaum muslimin. Dalam hal ini Allah berfirman:

Muhammad itu adalah utusan Allah dan orang-orang yang bersama dengan dia adalah keras terhadap orang-orang kafir, tetapi berkasih sayang sesama mereka. kamu lihat mereka ruku. dan sujud mencari karunia Allah dan keridhaan-Nya, tanda-tanda mereka tampak pada muka mereka dari bekas sujud ${ }^{1}$. Demikianlah sifat-sifat mereka dalam Taurat dan sifat-sifat mereka dalam Injil, yaitu seperti tanaman yang mengeluarkan tunasnya maka tunas itu menjadikan tanaman itu Kuat lalu menjadi besarlah dia dan tegak lurus di atas pokoknya; tanaman itu menyenangkan hati penanam-penanamnya karena Allah hendak menjengkelkan hati orang-orang kafir (dengan kekuatan orang-orang mukmin). Allah menjanjikan kepada orang-orang yang beriman dan mengerjakan amal yang saleh di antara mereka ampunan dan pahala yang besar.

Kesinambungan sifat rahmah dari Allah ke Rasulullah, terus kepada para sahabat akan membantu pembaca untuk mengenal karakter ajaran Islam yang diturunkan untuk seluruh umat manusia.

\section{Bentuk-bentuk Rahmat Dalam al-Quran}

Mengkaji tentang bentuk rahmat dalam al Quran bertujuan untuk mengetahui tingginya perhatian Allah terhadap manusia dan untuk mengetahui ruh ajaran Islam secara umum.

Bentuk rahmat Allah dalam al-Quran ada tiga : 1). Rahmat Allah untuk seluruh manusia; 2).Rahmat Allah yang khusus untuk orang yang beriman; 3). Rahmat Allah untuk seluruh makhluk ciptaan-Nya.

Pertama, Rahmat Allah untuk Seluruh Manusia. Dalam tataran konsep, Islam memberikan perhatian tinggi terhadap nilai-nilai kemanusiaan universal. Semua manusia mendapatkan rahmat ini, baik dia dekat dengan Allah maupun jauh, mukmin atau kafir. Menebar rahmat ini menjadi bagian dari tugas Nabi Muhammad saw sebagai komitmen dirinya untuk menjadi Rasul penebar rahmat buat semesta. Rahmat untuk manusia bisa dikelompokkan dalam empat kategori: pertama, rahmat yang terkait dengan fisik; kedua, rahmat terkait dengan batin atau non fisik; ketiga, rahmat yang terkait dengan fitrah; keempat, rahmat terkait dengan akal.

Karena kasih sayang dari Allah, semua manusia merasakan empat jenis rahmat di atas. Rahmat fisik di antaranya kesehatan, rezeki, kemampuan berkomunikasi, dll. 
Selain menyediakan kebutuhan dasar yang sifatnya fisik, Allah juga menyediakan kebutuhan lain manusia yang menjadi konsumsi batin, yaitu kebahagiaan, kenyamanan, kedamaian, dan ketenteraman. Kehadiran Nabi dengan membawa kitab suci adalah salah satu cara untuk memuaskan kebutuhan batin manusia.

Rahmat terkait dengan fitrah adalah dengan menyalurkan naluri manusia yang senang terhadap lawan jenis dan ingin hidup berpasangpasangan. Agar naluri ini tidak lepas kontrol, Dia menetapkan cara-cara yang sehat dan manusiawi. Dengan cara yang sehat dan manusiawi ini diharapkan tujuan pernikahan dapat tercapai, yaitu memenuhi kebutuhan psikologi yang mendambakan ketenangan, rasa cinta, dan kasih sayang. Selain untuk memenuhi kebutuhan psikologi suami istri, setiap pasangan juga diberikan kecenderungan untuk memiliki keturunan, meskipun saat melahirkan seorang ibu harus siap menghadapi sakitnya melahirkan. Orang tua yang mendapat titipan rasa kasih sayang dari Allah dipertemukan dengan anak yang membutuhkan belaian kasih sayang memiliki kenangan khusus yang tidak mungkin dilupakan oleh sang anak. Kebutuhan rasa aman juga mendapatkan perhatian besar dari Allah. Di antara sifat Allah adalah as Salam dan al Mu min, Yang menebar kedamaian dan Yang memberikan rasa aman. Dari-Nyalah kedamaian bersumber, dan kepada-Nyalah kedamaian kembali. Damai dan rasa aman Allah wujudkan dengan berbagai cara; ada yang bersumber dari kita sendiri, ada yang bersumber dari orang lain, ada yang dititipkan pada hewan dan tumbuhan, dan ada dalam bentuk perlindungan langsung dari Allah swt. Tangan, kaki, mulut, otak, dan nurani adalah di antara perangkat yang disediakan Allah agar manusia mampu membela diri dari orang yang berniat jahat terhadap dirinya. Selain menganugerahkan sifat kasih sayang sebagai sifat dasar manusia, Allah juga menitipkan rasa segan, tidak tega, tidak enak, merasa bersalah, dan malu untuk berbuat semena-mena terhadap orang lain. Perasaan-perasaan itulah yang membuat orang tidak berani melakukan kejahatan di depan publik dan berusaha bersembunyi saat melakukan kejahatan dan kecurangan. Allah juga menciptakan hewan dan tumbuhan yang bersahabat dengan manusia. Meskipun buas, ia lebih memilih menghindar dari komunitas manusia dan tidak akan menyerang kecuali dalam keadaan terpaksa.

Adapun bentuk rahmat terhadap akal di antaranya keinginan mengetahui rahasia langit dan bumi, memanfaatkan benda-benda yang ada di alam untuk diolah baik dengan tangan maupun dengan teknologi untuk kemudahan dan kemaslahatan hidup manusia. 
Kedua, Rahmat Allah yang spesial untuk orang beriman. Orang mukmin selain mendapatkan rahmat di atas juga mendapatkan tambahan rahmat karena keimanan mereka. Tetapi iman yang dimaksud di sini adalah iman yang hidup yang mampu mewarnai seluruh diri, bukan iman yang beku yang tidak menghasilkan apa-apa. Dengan iman yang hidup rahmat Allah akan bercucuran, menjadi lebih bermakna dan bernilai.

Secara umum, tambahan rahmat yang diperoleh orang mukmin terbagi dua : rahmat di dunia, dan rahmat di akhirat.

Di antara rahmat dunia untuk orang yang beriman adalah terjaga dari azab yang membinasakan secara total (QS. Hud:43), dibekali oleh Allah kecerdasan emosional yang tinggi. Mereka tidak mudah terjebak dalam pola berfikir pragmatis yang mengedepankan kesenangan sesaat dan masa bodoh dengan apa yang akan terjadi kemudian. (Al-Hasyr: 18). Rahmat Allah yang lain buat orang mukmin yang baik adalah tidak mudah takluk di bawah bujuk rayu syetan. Mereka berasal dari kalangan jin tapi sebagian berasal dari manusia. Kemampuannya menundukkan manusia sangat tinggi. Mereka bisa melihat manusia tanpa harus menampakkan dirinya, bahkan mampu menyelinap masuk disetiap gerak darah tanpa disadari oleh manusia. Rahmat lain yang diturunkan oleh Allah kepada sesama muslim adalah keinginan yang kuat untuk bersatu, hidup bersama dalam komunitas orang-orang shalih, tidak menyuburkan budaya saling mendengki, obyektif dalam menilai permasalahan, mudah memaafkan saudara mereka yang melakukan kesalahan. Kebersamaan yang dibangun di atas landasan iman membuat mereka unggul, tidak gampang di intervensi oleh kekuatan musuh, kerusakan bisa ditanggulangi bersama sehingga kemurkaan Allah tidak menghinggapi mereka.

Perbedaan paling utama mukmin dengan yang lain adalah rahmat akhirat. Orang-orang mukmin akan mendapatkan syafaat (QS. Maryam: 87), selamat dari azab akhirat (Al-Dukhan: 40-42), mendapatkan wajah yang putih bercahaya (QS. Al-Anfal: 24), dikeluarkan dari neraka, dan lulus syarat untuk masuk surga.

Ketiga, Rahmat Allah untuk seluruh makhluk-Nya. Di antara bentuk rahmat Allah untuk seluruh makhlukNya: mengatur seluruh urusan makhluk dari sejak diciptakan hingga dimatikan Al-An am: 59). Allah juga memerintahkan kita untuk berbuat baik dengan alam dan segala isinya dan tidak merusaknya (QS. Al-A raf: 56).

Tabel 1 Bentuk-bentuk Rahmat

\begin{tabular}{llll}
\hline Untuk Seluruh Manusia & Khusus & Untuk & Untuk Seluruh \\
\hline $10 \quad$ Ilmu Dakwah: Academic Journal for Homiletic Studies 11(1) (2017) 1-20
\end{tabular}


Makna dan Aktualisasi Dakwah Islam Rahmatan lil Alamin di Indonesia

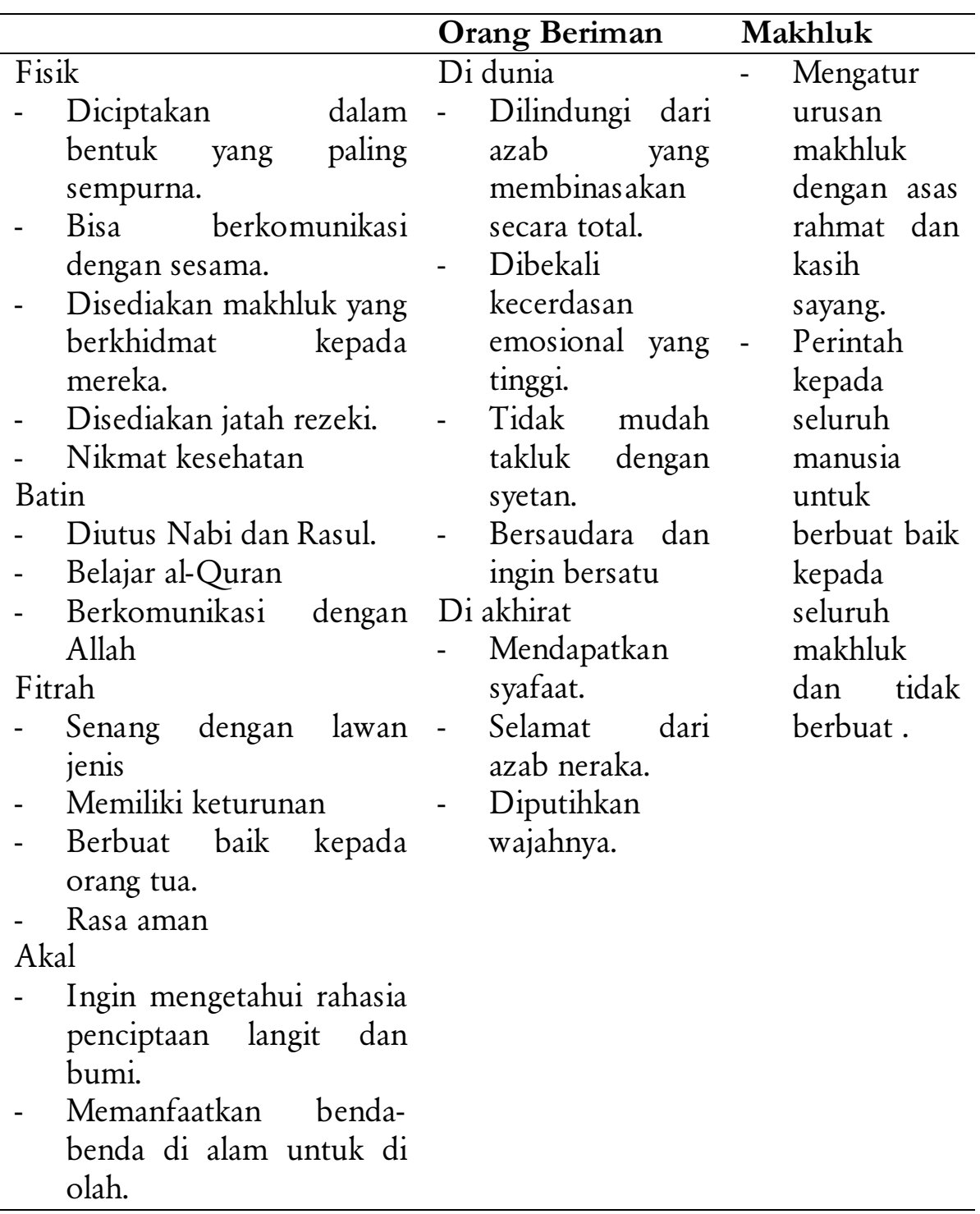

Bagan di atas menunjukkan cakupan dakwah rahmatan lil alamin yang menjadi tugas Nabi Muhammad saw dan menjadi tugas umat Islam. Bagan di atas juga menunjukkan tentang kesempurnaan dakwah Nabi saw yang mencakup seluruh aspek manusia, lahir, batin, fitrah dan akal, dunia dan akhirat, serta dakwah untuk peduli dengan lingkungan.

\section{Amal-amal Penyebab Turunnya Rahmat}


Di antara data yang peneliti temukan setelah menghimpun ayat-ayat tentang rahmat adalah data tentang amal-amal atau pekerjaan-pekerjaan yang menyebabkan turunnya rahmat Allah. Data ini peneliti yakini sebagai petunjuk Allah swt kepada Nabi agar melakukannya dan mengajarkan kepada umatnya untuk juga melakukannya. Di antara pekerjaan itu adalah:

1. Beriman kepada Allah dan berpegang teguh dengan keimanan. Allah berfirman:

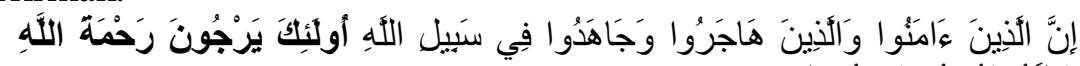

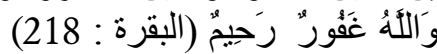

Sesungguhnya orang-orang yang beriman, orang-orang yang berhijrah dan berjihad di jalan Allah, mereka itu mengharapkan rahmat Allah, dan Allah Maha Pengampun lagi Maha Penyayang. (QS. Al-Baqarah: 218).

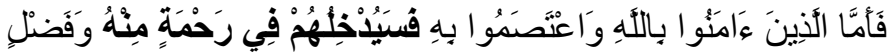

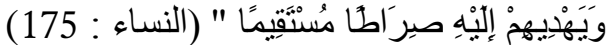

Adapun orang-orang yang beriman kepada Allah dan berpegang teguh kepada (agama)-Nya niscaya Allah akan memasukkan mereka ke dalam rahmat yang besar dari-Nya (surga) dan limpahan karuniaNya. dan menunjuki mereka kepada jalan yang lurus (untuk sampai) kepada-Nya.

2. Merasa diri banyak memiliki kekurangan dan berdoa supaya mendapatkan rahmat.

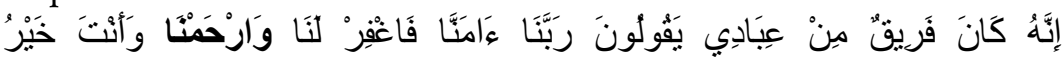

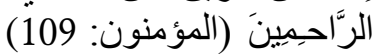

Sesungguhnya, ada segolongan dari hamba-hamba-Ku berdoa (di dunia): "Ya Tuhan kami, kami telah beriman, maka ampunilah kami dan berilah kami rahmat dan Engkau adalah pemberi rahmat yang paling baik. (QS. Al-Mu minun: 109).

وَقَلْ رَبِّ اغْفِرْ وَارْحَمْ وَأَنْتَ خَيَرُ الرَّاحِمِينَ " (المؤمنون : 118)

Dan Katakanlah: "Ya Tuhanku berilah ampun dan berilah rahmat, dan Engkau adalah pemberi rahmat yang paling baik." (QS. AlMu minun: 118).

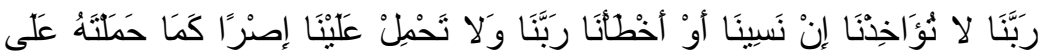

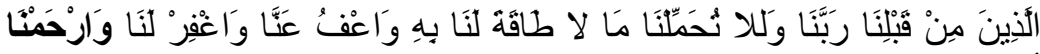




Allah tidak membebani seseorang melainkan sesuai dengan kesanggupannya. ia mendapat pahala (dari kebajikan) yang diusahakannya dan ia mendapat siksa (dari kejahatan) yang dikerjakannya. (mereka berdoa): "Ya Tuhan Kami, janganlah Engkau hukum Kami jika Kami lupa atau Kami tersalah. Ya Tuhan Kami, janganlah Engkau bebankan kepada Kami beban yang berat sebagaimana Engkau bebankan kepada orang-orang sebelum kami. Ya Tuhan Kami, janganlah Engkau pikulkan kepada Kami apa yang tak sanggup Kami memikulnya. beri ma.aflah kami; ampunilah kami; dan rahmatilah kami. Engkaulah penolong Kami, Maka tolonglah Kami terhadap kaum yang kafir." (QS. Al-Baqarah: 286).

3. Profesional dalam bekerja

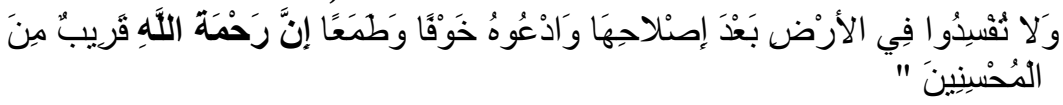

Dan janganlah kamu berbuat kerusakan di bumi setelah (diciptakan) dengan baik. Berdoalah kepada-Nya dengan rasa takut dan penuh harap. Sesungguhnya rahmat Allah sangat dekat dengan orang yang berbuat kebaikan. (QS. Al-A raf: 56).

4. Saling berwala dengan sesama mukmin

5. Amr ma ruf nahi munkar

6. Mendirikan sholat

7. Membayar zakat

8. Menaati Allah dan Rasul-Nya

Ayat-ayat yang menjelaskan tentang poin 4 sampai 8 sebagai penyebab turunnya rahmat adalah sebagai berikut:

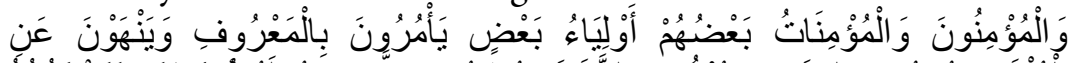

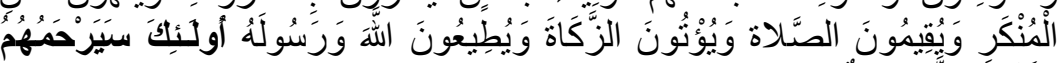

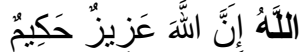

Dan orang-orang yang beriman, lelaki dan perempuan, sebahagian mereka (adalah) menjadi penolong bagi sebahagian yang lain. mereka menyuruh (mengerjakan) yang ma.ruf, mencegah dari yang munkar, mendirikan shalat, menunaikan zakat dan mereka taat pada Allah dan Rasul-Nya. Mereka itu akan diberi rahmat oleh Allah; Sesungguhnya Allah Maha Perkasa lagi Maha Bijaksana. (QS. AtTaubah: 71).

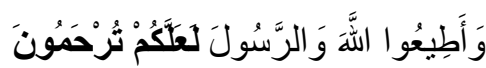

Dan taatilah Allah dan rasul, supaya kamu diberi rahmat. (QS. Ali Imran: 132) 


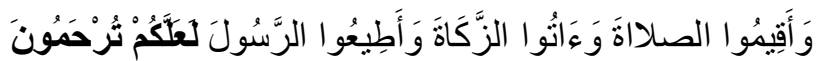

Dan dirikanlah sembahyang, tunaikanlah zakat, dan taatlah kepada rasul, supaya kamu diberi rahmat. (QS. An-Nur: 56).



Katakanlah: "Jika kamu (benar-benar) mencintai Allah, ikutilah Aku, niscaya Allah mengasihi dan mengampuni dosa-dosamu." Allah Maha Pengampun lagi Maha Penyayang. (QS. Ali Imran: 31)

9. Berbuat baik kepada orang tua

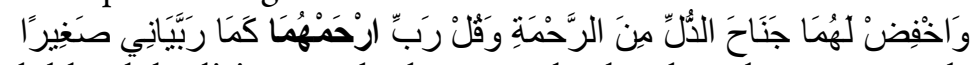

Dan rendahkanlah dirimu terhadap mereka berdua dengan penuh kesayangan dan ucapkanlah: "Wahai Tuhanku, kasihilah mereka keduanya, sebagaimana mereka berdua telah mendidik aku waktu kecil". (QS. Al-Isra : 24)

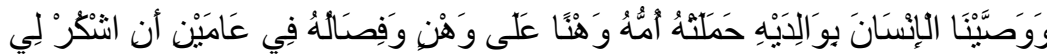

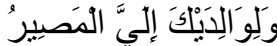

Dan Kami perintahkan kepada manusia (berbuat baik) kepada dua orang ibu- bapanya; ibunya telah mengandungnya dalam Keadaan lemah yang bertambah- tambah, dan menyapihnya dalam dua tahun. bersyukurlah kepadaku dan kepada dua orang ibu bapakmu, hanya kepada-Kulah kembalimu.

10. Mengikuti al-Quran dan mendengarkannya dengan seksama



Dan apabila dibacakan Al Quran, Maka dengarkanlah baik-baik, dan perhatikanlah dengan tenang agar kamu mendapat rahmat. (QS. AlA raf: 204)

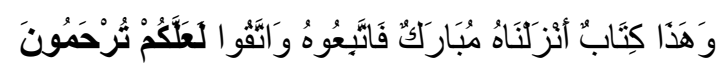

Dan Al-Quran itu adalah kitab yang Kami turunkan yang diberkati, maka ikutilah Dia dan bertakwalah agar kamu diberi rahmat. (QS. Al-An am: 155)

11. Bertaqwa

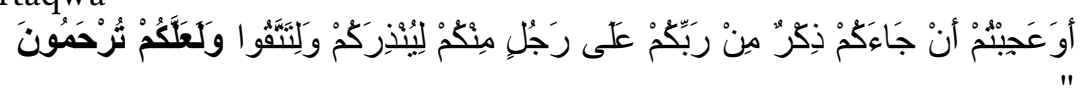

Dan Apakah kamu (tidak percaya) dan heran bahwa datang kepada kamu peringatan dari Tuhanmu dengan perantaraan seorang laki-laki dari golonganmu agar Dia memberi peringatan kepadamu dan 
Mudah-mudahan kamu bertakwa dan supaya kamu mendapat rahmat? (QS. Al-A raaf: 63).

12. Istighfar, taubat, sholat, dan memperbaiki diri

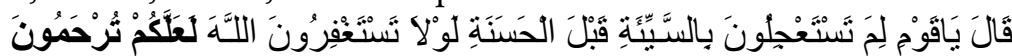

Dia berkata: "Hai kaumku mengapa kamu minta disegerakan keburukan sebelum (kamu minta) kebaikan? hendaklah kamu meminta ampun kepada Allah, agar kamu mendapat rahmat". (QS. An-Naml: 46).



Jika mereka bertaubat dan mendirikan sholat dan menunaikan zakat, Maka berilah kebebasan kepada mereka untuk berjalan. Sesungguhnya Allah Maha Pengampun lagi Maha Penyayang. (QS. At-Taubah: 5).

13. Ukhuwwah yang dibangun di atas dasar taqwa



Orang-orang beriman itu sesungguhnya bersaudara. Sebab itu damaikanlah (perbaikilah hubungan) antara kedua saudaramu itu dan takutlah terhadap Allah, supaya kamu mendapat rahmat. (QS. AlHujurat: 10)

14. Sabar ketika menghadapi musibah

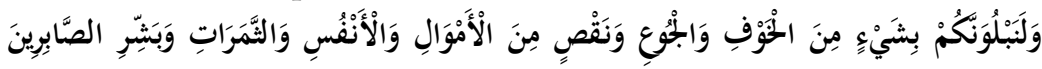

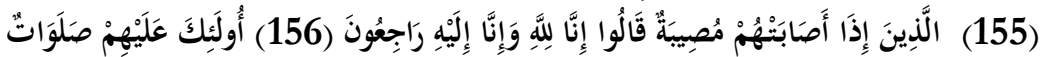

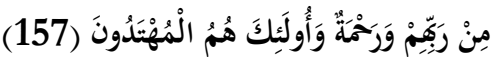

Dan sungguh akan Kami berikan cobaan kepadamu, dengan sedikit ketakutan, kelaparan, kekurangan harta, jiwa dan buah-buahan. dan berikanlah berita gembira kepada orang-orang yang sabar. (yaitu) orang-orang yang apabila ditimpa musibah, mereka mengucapkan: "Inna lillaahi wa innaa ilaihi raaji.uun". Mereka itulah yang mendapat keberkatan yang sempurna dan rahmat dari Tuhan mereka dan mereka Itulah orang-orang yang mendapat petunjuk. (QS. AlBaqarah: 155-157).

15. Hijrah

16. Berjihad dengan harta dan jiwa

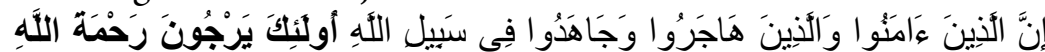

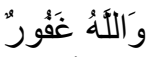




Sesungguhnya orang-orang yang beriman, orang-orang yang berhijrah dan berjihad di jalan Allah, mereka itu mengharapkan rahmat Allah, dan Allah Maha Pengampun lagi Maha Penyayang. (QS. Al-Baqarah: 218)

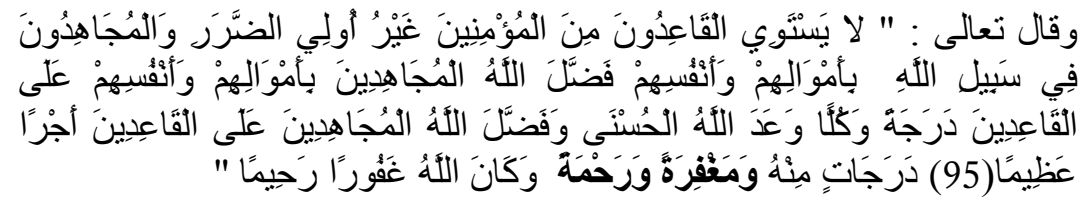

Tidaklah sama antara mukmin yang duduk (yang tidak ikut berperang) yang tidak mempunyai .uzur dengan orang-orang yang berjihad di jalan Allah dengan harta mereka dan jiwanya. Allah melebihkan orang-orang yang berjihad dengan harta dan jiwanya atas orang-orang yang duduk satu derajat. kepada masing-masing mereka Allah menjanjikan pahala yang baik (surga) dan Allah melebihkan orang-orang yang berijhad atas orang yang duduk dengan pahala yang besar, (yaitu) beberapa derajat dari pada-Nya, ampunan serta rahmat. dan adalah Allah Maha Pengampun lagi Maha Penyayang. (QS. AnNisa : 95-96).

17. Menjadi orang saleh

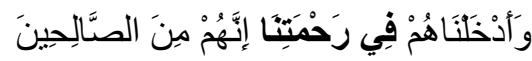

Kami telah memasukkan mereka ke dalam rahmat kami. Sesungguhnya mereka Termasuk orang-orang yang saleh. (QS. AlAnbiya : 86)

18. Infaq fi sabilillah untuk mendekatkan diri kepada Allah.

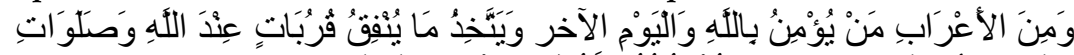

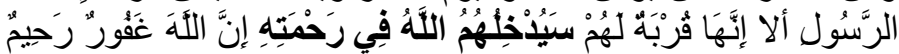

Di antara orang-orang Arab Badwi itu ada orang yang beriman kepada Allah dan hari Kemudian, dan memandang apa yang dinafkahkannya (di jalan Allah) itu, sebagai jalan untuk mendekatkannya kepada Allah dan sebagai jalan untuk memperoleh doa rasul. ketahuilah, Sesungguhnya nafkah itu adalah suatu jalan bagi mereka untuk mendekatkan diri (kepada Allah). Kelak Allah akan memasukan mereka kedalam rahmat (surga)Nya; Sesungguhnya Allah Maha Pengampun lagi Maha Penyayang. (QS. At-Taubah: 99)

19. Makan harta yang baik

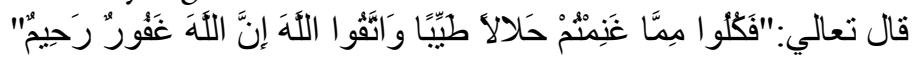


Maka makanlah dari sebagian rampasan perang yang telah kamu ambil itu, sebagai makanan yang halal lagi baik, dan bertakwalah kepada Allah; Sesungguhnya Allah Maha Pengampun lagi Maha Penyayang. (QS. Al-Anfal: 69)

20. Tawakkal kepada Allah

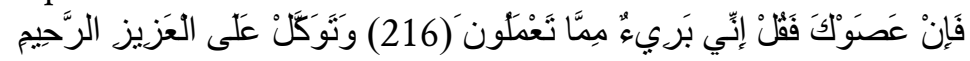

Jika mereka mendurhakaimu maka katakanlah: "Sesungguhnya aku tidak bertanggung jawab terhadap apa yang kamu kerjakan; Dan bertawakkallah kepada (Allah) yang Maha Perkasa lagi Maha Penyayang. (QS. Asy Syua ra : 216-217)

21. Berbuat baik kepada orang lemah, orang sakit, dan orang miskin

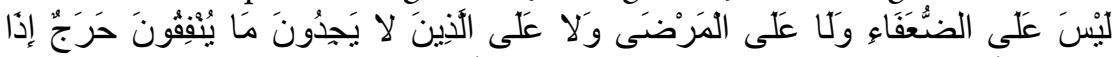

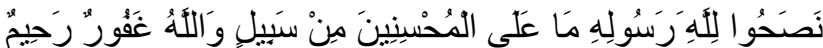

Tiada dosa (lantaran tidak pergi berjihad) atas orang-orang yang lemah, orang-orang yang sakit dan atas orang-orang yang tidak memperoleh apa yang akan mereka nafkahkan, apabila mereka Berlaku ikhlas kepada Allah dan Rasul-Nya. tidak ada jalan sedikitpun untuk menyalahkan orang-orang yang berbuat baik. dan Allah Maha Pengampun lagi Maha Penyayang. (At-Taubah: 91)

22. Mengkaji ayat-ayat Allah di masjid

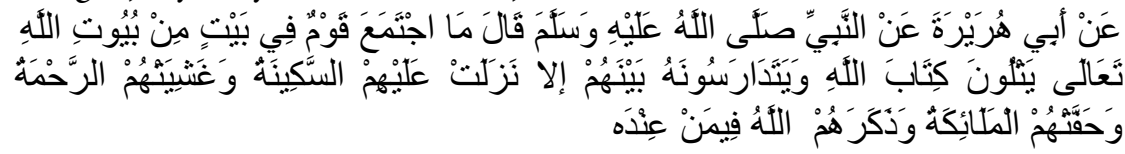

Dari Abi Hurairah, dari Nabi SAW bersabda: Tidaklah berkumpul suatu kaum di sebuah rumah Allah, mereka membaca Kitabullah dan mempelajarinya dengan sesama mereka, kecuali Allah akan turunkan ke atas mereka ketenangan, mereka akan dinaungi oleh rahmat, akan ditemani oleh malaikat, dan Allah akan menyebut mereka kepada siapa yang ada di sisi-Nya. Hadits ini ditemukan di Shah h Muslim (t.t.: 4867); Sunan Abi D wud (t.t.: 1243), Sunan al-Tirmidzi (1975: 2869); Sunan Ibni M jah (t.t.: 221), Musnad al-Imam Ahmad(2001: 7118), Sunan al-D rimi (2000: 348).

23. Memakmurkan masjid

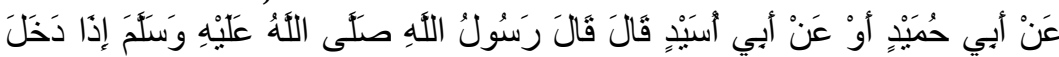



Dari Abi Humaid atau dari Abi Usaid berkata, Rasulullah SAW bersabda: Jika salah seorang di antara kalian masuk masjid, maka ucapkanlah Allahumma iftah li abwaba rahmatika dan apabila kelaurga ucapkanlah: Allahumma inni as aluka min fadhlika . Hadits 
ini ditemukan di Shah h Muslim (t.t.: 1165), Sunan al-Nas -I (1986: 721), Kit b al-Mas jid, no. 721, Sunan Abi D wud (t.t.: 292), Sunan Ibni M jah (t.t.: 7224), Musnad al-Imam Ahmad, Musnad al-Muktsir n (2001: 15477), Sunan al-D rimi (2000: 1358).

24. Berlomba melakukan kebaikan di antara suami dan istri

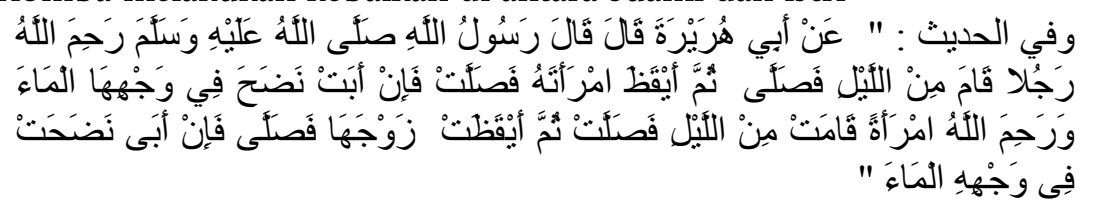

Dari Abi Hurairah berkata, Rasulullah SAW bersabda: Semoga Allah merahmati seseorang yang bangun pada malam hari, lalu dia bangun, setelah itu membangunkan istrinya dan istrinyapun sholat. Apabila dia menolak maka dia percikkan air ke wajahnya. Allah juga merahmati seorang istri yang bangun pada malam hari lalu dia sholat, kemudian dia bangunkan suaminya dan diapun sholat. Jika dia menolak, maka dia percikkan air kemukanya. Hadits ini ditemukan di Sunan al-Nas i (1986: 1592), Sunan Abi Dawud (t.t.: 1113), Sunan Ibnu (t.t: 1326),

Berdasarkan Duapuluh empat poin di atas adalah merupakan data yang peneliti temukan dalam al-Quran tentang perbuatan-perbuatan yang mendatangkan rahmat. Nabi diperintahkan Allah untuk mengajarkan kepada manusia hal-hal berikut:

1. Beriman kepada Allah dan berpegang teguh dengan keimanan.

2. Merasa diri banyak memiliki kekurangan dan berdoa supaya mendapatkan rahmat.

3. Profesional dalam bekerja

4. Saling berwala dengan sesama mukmin

5. Amr ma ruf nahi munkar

6. Mendirikan sholat

7. Membayar zakat

8. Menaati Allah dan Rasul-Nya

9. Berbuat baik kepada orang tua

10. Mengikuti al-Quran dan mendengarkannya dengan seksama

11. Bertaqwa

12. Istighfar, taubat, dan memperbaiki diri

13. Ukhuwwah yang dibangun di atas dasar taqwa

14. Sabar ketika menghadapi musibah

15. Hijrah

16. Berjihad dengan harta dan jiwa

Ilmu Dakwah: Academic Joumal for Homiletic Studies 11(1) (2017) 1-20 
17. Menjadi orang saleh

18. Infaq fi sabilillah untuk mendekatkan diri kepada Allah.

19. Makan harta yang baik

20. Tawakkal kepada Allah

21. Berbuat baik kepada orang lemah, orang sakit, dan orang miskin

22. Mengkaji ayat-ayat Allah di masjid

23. Memakmurkan masjid

24. Berlomba melakukan kebaikan di antara suami dan istri

Keduapuluh empat materi di atas dapat dikelompokkan dalam dua kategori besar, yaitu: materi tentang hablun minallah dan materi tentang hablun minannas.

Materi yang masuk kategori hablun minallah adalah:

1. Beriman kepada Allah dan berpegang teguh dengan keimanan.

2. Menaati Allah dan Rasul-Nya.

3. Mendirikan sholat

4. Memakmurkan masjid

5. Mengkaji ayat-ayat Allah di masjid

6. Merasa diri banyak memiliki kekurangan dan berdoa supaya mendapatkan rahmat

7. Istighfar, taubat, dan memperbaiki diri

8. Mengikuti al-Quran dan mendengarkannya dengan seksama

9. Bertaqwa

10. Berjihad dengan harta dan jiwa

11. Sabar ketika menghadapi musibah

12. Tawakkal kepada Allah

Materi Tentang Hablun Minannas

1. Profesional dalam bekerja

2. Saling berwala dengan sesama mukmin

3. Amr ma ruf nahi munkar

4. Membayar zakat

5. Berbuat baik kepada orang tua

6. Ukhuwwah yang dibangun di atas dasar taqwa

7. Hijrah

8. Menjadi orang saleh

9. Infaq fi sabilillah untuk mendekatkan diri kepada Allah.

10. Makan harta yang baik

11. Berbuat baik kepada orang lemah, orang sakit, dan orang miskin

12. Berlomba melakukan kebaikan di antara suami dan istri

Temuan menarik dari dikumpulkannya ayat-ayat tentang rahmat adalah adanya keseimbangan jumlah tema yang terkait dengan hablun 
minallah dan hablun minannas, yaitu sama-sama dua belas. Kesamaan jumlah tema hablun minallah dan hablun minannas menunjukkan bahwa keseimbangan dua tema di atas merupakan prasyarat terwujudnya Islam rahmatan lil alamin.

\section{PENUTUP}

Rahmatan lil alamin adalah visi dakwah Rasulullah yang mengajak manusia kepada keselamatan hidup dengan konsep keseimbangan hubungan manusia-Pencipta dan manusia-manusia dengan semangat dasar kelembutan dan kasih sayang. Semua perbuatan yang diperintahkan oleh Islam meskipun lahirnya bertentangan dengan makna kelembutan dan kasih sayang seperti jihad, amar ma ruf nahi munkar hakikatnya mengandung makna kelembutan dan kasih sayang. Untuk membuktikan kebenaran konsep ini diperlukan penelitian tersendiri yang membahas kelembutan dan kasih sayang dibalik perintah jihad dan amar makruf nahi munkar.

\section{DAFTAR PUSTAKA}

Abu Dawud, S. bin al-A. bin I. bin B. bin S. bin Amr al-A. al-S. (t.t.). Sunan Abi Dawud. Beirut: al-Maktabah al- Ashriyyah.

Al-Darimi, A. M. A. bin A. bin al-F. bin B. bin A. (2000). Sunan AI$D$ rimi. Saudi Arabia: Dar al-Mughni.

Al-Nasa i, A. A. A. bin S. bin A. al-K. (1986). Sunan al-Nasa i, Cet.2. Halb: Maktabah al-Mathbu at al-Islamiyyah.

Al-Tirmidzi, M. bin I. bin S. bin M. bin al-D. (1975). Sunan al-Tirmidzi. Mesir: Maktabah Mushtafa al-Babi al-Halabi.

Hanbal, A. A. A. bin M. bin. (2001). Musnad al-Imam Ahmmad. Beirut: Muassasah al-Risalah.

Ibnu Majah, A. A. M. bin Y. al-Q. (t.t.). Sunan Ibni Majah. Beirut: Dar Ihya al-Kutub al- Arabiyyah.

Muslim bin al-Hajjaj, A. al-H. al-Q. al-N. (t.t.). Shahih Muslim. Beirut: D $r$ Ihy al-Tur ts al- Arabi.

Nata, A. (2016). Islam Rahmatan lil Alamin Sebagai Model Pendidikan Islam Memasuki Asean Community. dalam Kuliah Tamu Jurusan Pendidikan Agama Islam Fakultas IImu Tarbiyah dan Keguruan UIN Maulana Malik Ibrahim Malang. Malang: UIN Maulana Malik Ibrahim. 